\title{
ハラアカコブカミキリの羽化時期と体長の変異
}

大長光 純 (福岡県林業試験場)

\begin{abstract}
Occurrence and size variation of the oak longicorn beetle, Moechotypa diphysis (Pascoe). Jun ONagamitu (Fukuoka Prefectural Forest Experiment Station, Kurogi, Fukuoka 834-12)
\end{abstract}

ハラアカコブカミキリ Moechotypa diphysis (PASCOE) はわが国では対馬だけに生息していたが，対馬から持ち 込まれたシイタケほだ原木に伴って九州本土に侵入し 定着してしまった。福岡県でも上陽町において，対馬産 のほだ木から1978年に発生が確認され（金子，1981）， その後シイタケ栽培地を中心に分布を広げ, 福岡県での 主要なシイタケほだ蛪となっている。被害防除に資 するため当林業試験場では生態や加害機構についての研 究を行っているが, 成虫の羽化消長は1978年発生のもの については寸でに発表した（大長光・金子，1980）。本 論文では, その後の羽化状態, 特に羽化時期の年変動お よび习习化時期と体長・体重との関係について調査した結 果を報告する。

\section{材料と方 法}

八ラアカコブカミキリは通常 1 年一化性で, 春から初 夏に産甽し新成虫はその年の秋に羽化し盛んに後食し成 虫で越冬，翌春交尾産卵を行う。成虫の羽化消長の調査 を，1978，1979，1980，1982年の4 か年行った。調査用 のほだ木は，福岡県八女郡上陽町尾久保（標高 $400 \mathrm{~m}$ ) で截培されていたほだ木を毎年使用した。ハラアカコブ カミキリの産卵痕の付いた 1 年生シイタケほだ木（クヌ ギ）を採取し，8月中旬に当林業試験場構内の網室内に 運び込み，年内に羽化してくる成虫を每日採集した。使 用したほだ木の大きさは，長さ $1 \mathrm{~m}$, 中央径が $3 \sim 5 \mathrm{~cm}$ の小径木である。体長ならびに体重の測定は，1979年の 羽化成虫についてのみ探集当日に行った。測定方法は, 体重は直示天科を用い $10 \mathrm{mg}$ 単位で，体長はノギスを用い $0.1 \mathrm{~mm}$ 単位で計測した。

\section{結}

果

羽化消長を第 1 図に示す。1978年と1980年は, 羽化期 初期である 8 月下旬から9月上旬にかけて発生ピークが あり，そ机以降は漸減傾向を示した。ところが1979年と 1982年はやや遅れて 9 月中一下旬に発生の山が諗められ

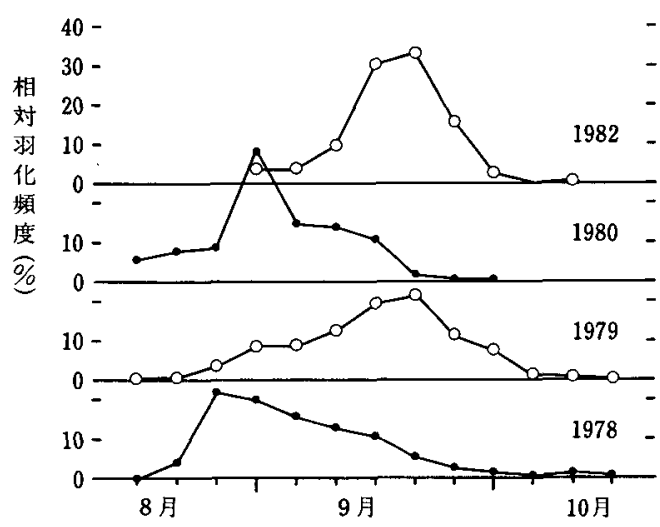

第1図 ハラアカコブカミキリの羽化消長

第1表 ハラアカコブカミキリの羽化数と性比

\begin{tabular}{ccrrr}
\hline \hline 年 & 調查ほだ数 & \multicolumn{1}{c}{ 今 } & \multicolumn{1}{c}{ 早 } & 令 $/$ 早 \\
\hline 1978 & 600 & 1528 & 1640 & 0.932 \\
1979 & 400 & 996 & 978 & 1.018 \\
1980 & 63 & 69 & 66 & 1.045 \\
1982 & 50 & 88 & 90 & 0.978 \\
\hline
\end{tabular}

た。なお雌雄の発生パターンはほぼ同一で，雄の方が先 に羽化するというような傾向は示さなかった。また，羽 化数と性比について第 1 表に示したが, 性比はほぼ 1 対 1 であった。

1979年の羽化個体の体長・体重について第 2 表に，羽 化時期と成虫の体長 - 体重の関係について第 2,3 図に 示す。体長・体重いずれも雌の方が雄よりもやや大きく， 雌雄とも羽化時期が遅くなるにつれて経時的に小さくな った。

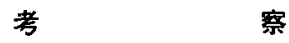

年によって発生のビークが変動するのは，気象要因が 原因かもしれない。そこでハラアカコブカミキリの成育 期である 4 月から 9 月までの気温と降水量について検討 した (第 3 表)。1978年は6ー7月がやや高温で, 雨量 
第 2 表 ハラアカコブカミキリの体長と体重（1979年）

\begin{tabular}{|c|c|c|c|c|c|c|}
\hline & 個 体 数 & & 平均 & 標準偏差 & 最大値 & 最小値 \\
\hline 雙 & 978 & $\begin{array}{l}\text { 体 長 } \mathrm{mm} \\
\text { 体重 } \mathrm{g}\end{array}$ & $\begin{array}{c}21.14 \\
0.536\end{array}$ & $\begin{array}{l}2.10 \\
0.169\end{array}$ & $\begin{array}{c}25.9 \\
0.99\end{array}$ & $\begin{array}{r}14.6 \\
0.19\end{array}$ \\
\hline 雄 & 996 & $\begin{array}{l}\text { 体 長 mm } \\
\text { 体重 } \mathrm{g}\end{array}$ & $\begin{array}{c}19.91 \\
0.473\end{array}$ & $\begin{array}{l}2.20 \\
0.156\end{array}$ & $\begin{array}{l}25.5 \\
0.90\end{array}$ & $\begin{array}{c}13.6 \\
0.12\end{array}$ \\
\hline
\end{tabular}

第 3 表 月毎の平均気温と降水量（黒木町, 標高 $105 \mathrm{~m}$ ）

\begin{tabular}{|c|c|c|c|c|c|c|c|}
\hline & & 4 月 & 5 月 & 6 月 & 7 月 & 8 月 & 9 月 \\
\hline \multirow[t]{2}{*}{ 1978年 } & 気 温 ${ }^{\circ} \mathrm{C}$ & 13.2 & 18.7 & 23.0 & 27.0 & 27.0 & 23.3 \\
\hline & 降 水 量 mm & 119 & 76 & 271 & 149 & 61 & 176 \\
\hline \multirow[t]{2}{*}{ 1979年 } & 気 温 & 13.5 & 17.0 & 22.8 & 25.3 & 26.5 & 23.2 \\
\hline & 降水量 & 159 & 84 & 763 & 255 & 101 & 133 \\
\hline \multirow[t]{2}{*}{ 1980年 } & 気 温 & 13.1 & 18.0 & 22.5 & 24.6 & 24.5 & 21.2 \\
\hline & 降水量 & 164 & 252 & 206 & 1159 & 721 & 158 \\
\hline \multirow[t]{2}{*}{ 1982年 } & 気 温 & 13.3 & 19.4 & 21.5 & 24.0 & 25.7 & 21.3 \\
\hline & 降水量 & 136 & 108 & 65 & 861 & 128 & 128 \\
\hline
\end{tabular}

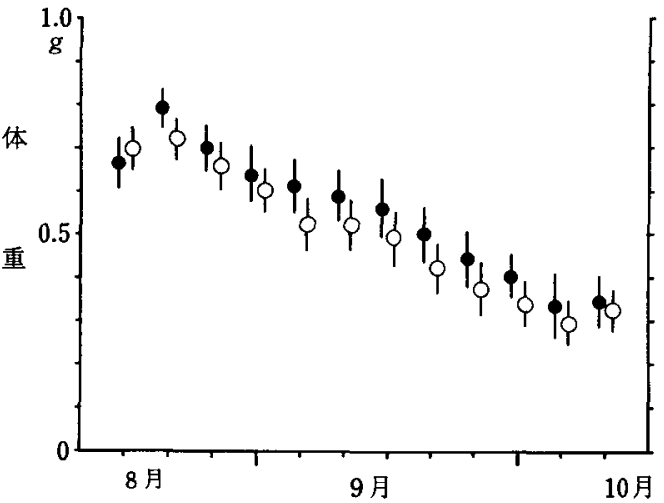

第2図 ハラアカコブカミキリの羽化時期と体長の関係 平均值と95\%信頼区間を示す。傩, ○雄

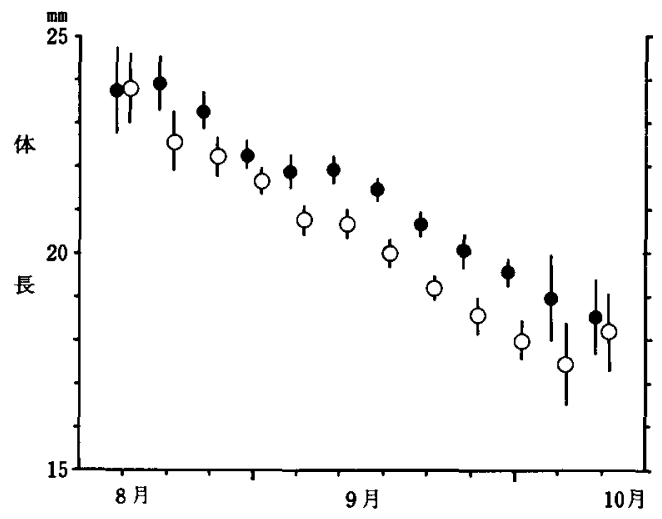

第 3 図 ハラアカコブカミキリの羽化時期と体重の関係 平均值と $95 \%$ 信頼区間を示す。雌，○雄

つぎに羽化時期が荤れることにより体長や体重が小さ くなることの原因と意味について考察する。初期に発生 する大型個体は早期に産卵され，後期の小型個体は晚期 に産卵されたものかもしれない。ハラアカコブカミキリ の幼蛹期間はほとんど樹皮直下で生活するため，飭木 が古くなればなるほど樹皮がはげ落ちやすくなり生有に 不適となる。そのため後から産卵されたものは小型個体 であっても年内に羽化する可能性が考えられる。事実， 越冬はほとんど成虫態で行われ，幼虫で越冬するものは

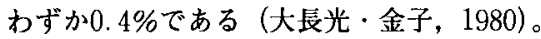


八ラアカコブカミキリのサイズについての詳しい報告 はほとんどないが, 藤本（1978）が対馬産について雄 $21.9 \pm 1.6 \mathrm{~mm}$, 雌 $23.0 \pm 2.3 \mathrm{~mm}$ と報告し, 今回の上陽町産 よりもやや大きい。今後は年や産地によってサイズにど の様な変動が現われるか，またそれが加害や生活力にど の様に影響するかについて調査する必要がある。
引用文献

1）藤本幸夫（1978）長猗県総合農林試験場研究報告（林業部

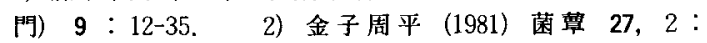
28-31. 3) 大長光純（1981）日林九支研論 34:193-194. 4) 大長光純·金子周平 (1980) 日林九支研論 33:131-132.

(1989年 4 月19日 受領) 